\title{
Therapeutic Massage Impacts Quality Of Life For University Female Faculty In Teacher Education
}

Clarine Sandstrom, Ph.D \& LMT, Minot State University, USA

\begin{abstract}
Stress is a part of everyone's life. Depending on the level of stress, it may affect people's health and lives. Stress in the workplace may come from many different sources, however for the purpose of this study, the focus was on female faculty working in a Teacher Education program at a small north central, North Dakota university. Stress is repeatedly prevalent among female faculty. They typically spend long hours at work, and thus have less time for other things. Stressed female faculty may feel emotionally taxed and thus produce nominally. Stress may deteriorate social and family relationships and ultimately may take a toll on their health. Therapeutic massage has been proven to be a stress reliever and thus may be helpful in enhancing the quality of life among the female faculty. This study examined whether therapeutic massage reduces stress and improves the overall quality of life of female faculty working in a Teacher Education program. Specific questions posed by the study have been answered by exploring perceptions of quality of life and clinical outcomes of therapeutic massage treatments. The results of the study were shared in presentations at the North Dakota American Massage Therapist Association conference in Bismarck, North Dakota and at the national Teaching Professors' conference in Atlanta, Georgia.
\end{abstract}

Keywords: holistic health, massage therapy, mind, body, and spirit, quality of life, stress,

\section{INTRODUCTION}

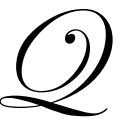

uality of life for higher education female faculty working in University Teacher Education programs is impacted by stress on a daily basis. During my four years of service to the University, I have observed stress in academic women on the campus. This stress has been contributed to by a variety of factors. First, there appears to be under-representation of women on the campus. Issues of faculty salary equity, promotion, and tenure are also factors that contribute to the overall quality of life. More female then male faculty serve in adjunct positions (Minot State University Fact Book, 2005). These workplace factors have a tendency to increase levels of stress in female faculty working in the University Teacher Education program.

\section{BACKGROUND TO THE STUDY}

The concern regarding stress and quality of life of female faculty working in the University Teacher Education program has emerged as an issue for study. Observation has led to conclude that women are not only expected to be exemplary professional models, they are also expected to be good wives, loving mothers, and community members. These competing expectations appear to provide a kind of stress that male counterparts rarely experience. Bernas and Majors (2002) indicate that even male colleagues who are emotionally supportive of women academics can assign them work tasks that exacerbate work interference with their family relationships.

Another factor that comes into play for female faculty is the concern about being taken seriously as professionals. Female faculty tend to have to prove they are capable of bearing their career path as well or better than their male colleagues (Theisen, 1997). 
Teaching loads, to include overloads, committee service, advising of students, and research expectations add to the stress level. Female faculty tend to accede to institutional demands such as service and research, to devote time to teaching and serving students (Washburn, 2004). They appear to have less time to conduct research and publish, which results in more of a mismatch between instructional demands and the perspectives of women.

Because of the concern for female faculty, I made a decision to study the problem to determine what effects the holistic health alternative practice of therapeutic massage designed to relax and revitalize the mind, body, and spirit had on stress reduction and overall quality of life

\section{THERAPEUTIC MASSAGE IMPACTS QUALITY OF LIFE}

The signs of stress, such as headaches, neck, shoulder, and lower back pain, lack of sleep and rest, noise in limited areas of space, feelings of anger and dissatisfaction in female colleagues in a collegiate teacher education program troubled me. Their heavy loads in the classroom, on committees, and advising students gave them less time for research and publication, which in turn meant they faced greater challenges than our male cournterparts in achieving promotion and tenure.

In addition to being exemplary professional models these women often spoke of the stress they felt in meeting expectations to be good wives, loving mothers, and contributing community members. Ultimately, I recognized their health would suffer.

As a licensed massage therapist with her own home-based business, I know that therapeutic massage and the importance of touch are about communication on the most basic level. This special communication that takes place improves relationships and helps to heal the body, mind, and spirit. I chose to marry my two worlds; education and massage therapy, for my doctoral dissertation to determine the effects of therapeutic massage on stress and quality of life among female colleagues at Minot State University in central North Dakota. Minot State, founded in 1913, is part of the North Dakota state university system with about 3,700 students.

I mailed a quality of life and stress survey, based on John D. and Catherine T. MacAruthur's Perceived Stress Scale, to 27 women on September 5, 2006. From that group, a randomly selected experimental group of 15 women received three one-hour therapeutic massage treatments between September 5 and October 31, 2006. The massages were designed to reduce stress and to relax and revitalize the body, mind, and spirit. In November, I mailed all participants a "post-quality of life and stress" survey.

In the initial survey, the women identified similar stressors: demands at work, feelings of being overextended, unrealistic expectations, and too little time to complete all tasks. The group selected for massage treatments showed significantly higher stress levels. Typical comments about stress included:

- $\quad$ Accreditation: confusion, changes, uncertainty of what is needed

- $\quad$ Teaching so many low-credit classes, because there are so many preparations

- $\quad$ The many unexpected needs of students and the department...I already have a full schedule

- $\quad$ Lack of time for all things, lack of balance in my life; too work centered.

- Having a chair who does not understand my job, that I have responsibilities that go beyond teacher ed

Stressors appeared to impact quality of life by causing feelings of anxiety, aloneness, physical, emotional, and mental fatigue, apprehension, and lack of trustworthy relationships with superiors. The women's responses reflected a loss of control of their lives with so many demands, so little time, and a lack of support to make things better.

Ways in which the women said they managed stress included:

- I I try to focus on a long view, that things will usually resolve themselves.

- I I hang out with friends as often as possible. 
- $\quad$ I have anxiety attacks, take meds for depression; may overeat, shop or smoke when upset.

- I tend to stuff it."

Activities the women engaged in to manage stress included exercise, prayer, visiting with friends, reading for pleasure, watching movies, and eating. Women in the control group were not participating in stress reduction activities other than those in which they regularly engage. For those in the experimental group, I chose the following massage techniques for each of the three massage sessions: myofacial release, and deep tissue massage, acupressure, stone massage therapy, and Reiki energy work. These specific techniques were integrated throughout each massage and were conducted with personal reflection to the needs of each participant, while allowing me to extend and enhance the health benefits and provide variety.

The major contribution of myofacial release and deep tissue therapy, acupressure, stone massage and Reiki therapy, whether practiced separately or in combination, is achieving harmony of the whole. Therefore, the ultimate goal of therapeutic massage is the restoring, revitalizing, and rejuvenating the body, mind, and spirit. Massage sessions were uniquely and personally designed to reduce stress, and to relax and revitalize the body, mind, and spirit of each participant.

Prior to the participant's therapeutic massage treatment, each woman completed a pre-massage survey assessment indication her environmental, physical, mental, emotional, and spiritual stress level, then completed the same survey again two days after their massage.

At the end of the study, the women in the experimental group reported significantly lower stress levels and improved quality of life vs. the control group (Table 1). Environmental, chemical, physical, mental, emotional, and spiritual stress levels were reduced significantly. Comments included:

- $\quad$ This is unreal - no pain and my attitude is more positive.

- I Ihink massage therapy will become a habit.

- I I am more relaxed as a result of the massages.

- I noticed that I think more clearly and focus better during the day.

- I Im sleeping more restfully and not waking up during the night.

- Having massages is helpful to stress reduction. I know it has improved my life on a daily basis.

Table 1: Perceived Stress Scale Results

\begin{tabular}{|l|l|l|l|l|l|c|c|}
\hline & & $\boldsymbol{n}$ & $\boldsymbol{M}$ & $\boldsymbol{S D}$ & $\boldsymbol{M d n}$ & $\boldsymbol{T}$ & $\boldsymbol{P}$ \\
\hline \multirow{2}{*}{ Pre-Stress Scale Total } & Control & 12 & 17.75 & 6.62 & 18.50 & \multirow{2}{*}{-5.12} & \multirow{2}{*}{$0.000^{*}$} \\
\cline { 2 - 6 } & Experimental & 15 & 29.07 & 4.28 & 28.00 & & \\
\hline \multirow{2}{*}{ Post-Stress Scale Total } & Control & 12 & 19.17 & 5.98 & 21.00 & \multirow{2}{*}{3.20} & $0.005^{*}$ \\
\cline { 2 - 6 } & Experimental & 15 & 12.80 & 3.80 & 12.00 & & \\
\hline
\end{tabular}

*Indicates significance at the $\alpha=0.05$ level. A $p$-value of 0.000 indicates $p<0.0001$.

Participants who received massage therapy became more relaxed, thus revitalizing the body, mind, and spirit by reducing stress and improving their quality of life at work and at home. I encourage female faculty to pursue massage as a way to manage stress and improve their qualify of life.

\section{CONCLUSIONS DETERMINED BY THE STUDY}

The following conclusions were drawn as a result of the research conducted on massage therapy and applied to the study of the Effects of Therapeutic Massage on Stress and Quality of Life of Female Faculty Working in the Teacher Education Program at a Small, North Central North Dakota University:

1. Therapeutic massage restores balance between mind, body, and spirit, resulting in homeostasis. 
2. Therapeutic massage improves blood circulation without putting any extra strain on the heart. Improved circulation increases the supply of oxygen and nutrients to all areas of the body, revitalizing mind, body, and spirit.

3. Therapeutic massage helps to move the lymph through the body, thus eliminating waste and strengthening the immune system.

4. Therapeutic massage affects the nervous system, and can have either a sedative or a stimulating effect that relaxes and revitalizes sensory and motor nerves and the autonomic nervous system.

5. Therapeutic massage, combined with psychological benefits of feeling cared for and cosseted, produce a marvelous feeling of well-being, because stress is reduced. Quality of life is perceived to improve for the client and the therapist.

The results of this study provide solid evidence to support my recommendation that all faculty should have access to therapeutic massage as a holistic health alternative.. Creating massage therapy centers as a part of campus wellness programs should improve overall quality of life - in and out of the university setting.

\section{AUTHOR INFORMATION}

Dr. Sandstrom serves as a tenured assistant professor in Teacher Education at Minot State University in Minot, North Dakota. Prior to coming to Minot State, Dr. Sandstrom served 32 years in North Dakota rural and urban school districts as a teacher and an elementary principal. Through innovative and careful planning, Dr. Sandstrom was able to secure a ND Comprehensive School Reform Grant for one of elementary schools she served and led a greater community effort involving faculty, parents, community members, and students to secure National Blue Ribbon School recognition for her school.

In addition to her service as an educator, Dr. Sandstrom has pursued a keen interest in the alternative health practice of massage therapy, and obtained her massage therapy license in 1998. She owns and operates CS Therapeutic Massage, Enterprise - a home based business which focuses on integration of current research and best practices in massage therapy. .Dr Sandstrom chose to integrate her two worlds of study and as doctoral dissertation determined the effects therapeutic massage had on stress reduction and improved quality of life among female colleagues at Minot State University in central North Dakota.

\section{REFERENCES}

1. About: Stress Management (2006). How to use spirituality for stress relief. Retrieved March 13, 2007 from http://www.stress.about.com/od/optimismspirituality/ht/spritiual.htm

2. Active Massage (2003). Connective tissue massage. Retrieved September 19, 2005, from http://www.activemassage.com/ctm.htm

3. Alexandra, S. (2003). Stone massage therapy: A catalyst for health enhancement. Retrieved September 16, 2005, from http://www.massagetoday.com/archives/2003/11/15.html

4. Allardt, E. (1975). Attha, alska, att vara: Om valford. (Having, loving, being in Nordic countries). Argos: Borgholm. (This book was borrowed from a fellow therapist who studied in Sweden).

5. American Music Therapy Association (n. d.). Frequently asked questions about music therapy. Retrieved September 15, 2005, from http://www.musictherapy.org/faqs.html.

6. $\quad$ Aspire.org. (n. d.). Walking meditation. Retrieved September 12, 2005, from http://www.apire.org/walk.html

7. Beck, E. (2001). Music therapy for less stress and better health. Retrieved September 15, 2005, from http://www. immunesupport.com/library/showarticle.cfm/ID/317/e/l/T/CFIDS FM

8. Bernas, K. \& Major, D. (2002). Contributors to stress resistance: Testing a model of women's work and family conflict. Psychology of Women Quarterly, 24, 170-178.

9. Bhattacharya, S. (n.d). The walk of life. Retrieved September 12, 2005, from http://www. lifepositive.com/Body/new-age-therapies/walk-therapy/walk-around.asp

10. BioHealth Information (2002). Managing mental and emotional health. RetrievedMarch 13, 2007 from http://www.biohealthinfo.com/html 
11. Body Wisdom Massage Therapy School (n. d.). Myofacial release therapy. Retrieved February 25, 2005, from http://www.bodywisdomschool.com/myofasical therapy.htm

12. Carlson, R. \& Bailey, J. (1997). Slowing down to the speed of life: How to create a more peaceful, simpler life form the inside out. New York, NY: Harper-Collins.

13. Chetwynd, T. (1982). A dictionary of symbols. (Part of the Walk of Life article) Retrieved September 12 , 2005, from http://www. lifepositive.com/Body/new-age-therapies/walk-therapy/walk-around.asp

14. CHI Newsletter (2007). Stress relieves pain but blocks healing...so do anti-inflammatories. San Juan, CA: CHI Institute.

15. Davis, P. K. (1991). The power of touch. Carson, CA: Hay House.

16. Dew, J. P. (2003). Stone therapy: A discussion of current trends and findings. Retrieved September 16, 2005, from http://www.yoga.com/ydc/enlighten_document.asp?ID=271\&section=5\&cat=0

17. Fletcher, A., Hunt, B., \& Bulpitt, C. (1987). Evaluation of quality of life. Journal of Chronic Diseases, 40 (6), 557-566. This essay was written for presentation at an invited plenary session of the annual meeting of the International Society for Quality of Life held in Amsterdam, 7-10 in November 2001.

18. Gach, M.R. (1990). Acupressure's potent points. New York, NY: Bantam Books.

19. Hannen, S. (2003). Healing by design: Unlocking your body's potential to heal itself. Lake Mary, FL: Siloam.

20. Holistic online (1998). Spiritual stress. Retrieved March 13, 2007 from http://wwwholisticonline.com/stress/stress_spiritual.html

21. Kolk van der, B., McFarlane, A., \& Weisaeth, L. (1996). Traumatic stress: The effects of overwhelming experience on mind, body, and society. New York, NY: Guilford Press.

22. Lifepositive.com (n. d.). Autogenic training for stress: Working on the mind. Retrieved September 12, 2005, from http://www. lifepositive.com/Body/new-age-therapies/music-therapy/music-therapeutic.asp

23. Lifepositive.com (n. d.). How to meditate. Retrieved September 12, 2005, from http://www.lifepositive.com/Spirit/meditation/how-to-meditate.asp

24. Lifepositive.com (n. d.). How to meditate. Retrieved September 12, 2005, from http://www.lifepositive.com/Mind/psychology/stress-reduction.asp\#musictherapyandstress

25. Lifepositive.com (n.d). Meditation: How to mediate and channel awareness inward. Retrieved September 12, 2005, from http://www.lifepositive.com/meditation.asp

26. Lifepositive.com (n. d.). Walking for stress relief. Retrieved September 12, 2005, from http://www.lifepositive.com/Mind/psychology/stress/stress-reduction.asp

27. MacArthur, John D. \& Catherine, T. (1999). Perceived Stress Scale - 10 Item. Retrieved February 2, 2005 , from http://www.macses.ucsf.edu/research/Psychosocial/notebook/PSS10.html

28. Mally, J. (1996). Deep tissue massage. Roseville, CA: Abundant Health Resources.

29. Mama’s Health.com (2005). Deep tissue massage. Retrieved September 15, 2005, from http://www.mamashealth.com/massage/dtissue/asp

30. Massage Garden (2003). Massage kit, $2^{\text {nd }}$ ed. Carnation, WA: The Massage Garden.

31. Mattes, A. L. (1995). Active isolated stretching. Sarasota, FL: Aaron L. Mattes.

32. Maxwell-Hudson, C. (1988). The complete book of massage. New York, NY: Random House.

33. Michalos, A. C. (2001). Social indicators research and health-related quality of life research. British Columbia, Canada: University Press.

34. Michalos, A. C. \& Zumbo, B. D. (2001). Ethnicity, modern prejudice, and quality of life. Social Indicators Research, 48, 125-156.

35. Mind Tools, Ltd. (1995-2007). Managing chemical stress. Retrieved March 13, 2007 from Users/colab/desktop/managing\%20Chemical\%20Stress\%20Management\%20Techniques\%20from\%20Min d\%Tools.html

36. Minot State University Fact Book (2005). 2005 fact book. Minot, ND: MSU.

37. Nutrition Health Center (2007). Environmental stress. Retrieved March 13, 2007 from http://www.adddadhd-help-center.com/stress/environmentalstresshtm

38. Nutrition Health Center (2007). Reduce stress. Retrieved March 13, 2007 from http://www.addd-adhdhelp-center.com/stress/environmentalstress.htm

39. Peacefulmind.com (n.d). Treasures of the earth: History of hot stones. Retrieved February 5, 2005, from http://www.peacefulmind.com/hotstones.htm\#TREASURES\%20of20THE\%20Earth\%20History\%20of\%2 0Hot\%20Stones 
40. Quality of Life Research Unit (1994). The quality of life model. Retrieved February 16, 2005, from http://www.utoranto.ca/qol/concepts.htm

41. Renwick, R., \& Brown, I. (1996). The center for health promotion's conceptual approach to quality of life. Quality of Life in Health Promotion and Rehabilitation, pp 75-86. Thousand Oaks, CA: Sage.

42. Reuterhealth.com (2001).

43. Rissam, H. S. (n. d.). A hearty walk. Retrieved September 12, 2005, from http://www.lifepositive.com/Body/new-age-theapies/walk-therapy/walking-wellbeing.asp

44. SpringerLink (2005). The functional state of the central nervous system in chemical stress. Retrieved March 13, 2007 from http://www.SpringerLink\%20-\%20journal\%article.html

45. Theisen, C. (1997). Mothering in the tenure track: Can we do it all? Women in Higher Education, 6, 22-23

46. Thie, J., DC (1994). Touch for health: A practical guide to natural health with acupressure, touch, and massage. Marin del Rey, CA: DeVorss.

47. Vhi Healthcare (2007). Spiritual stress. Retrieved March 13, 2007 from http://www.vhi.ie/experts/stress/str_Q091.jsp

48. Walter, S. (1996). Holistic health. Retrieved February 4, 2005 from http://www.ahha.org/articles.asp?Id=85

49. Washburn, M. H. (2004). Appeasing women faculty: A case study in gender politics. Retrieved January 14, 2005 from http://www.advancingwomen.com/awl/spring2004/WASHBURN.html 